\title{
THE DEBATE ON \\ THE ENGLISH \\ REFORMATION
}

SECOND EDITION

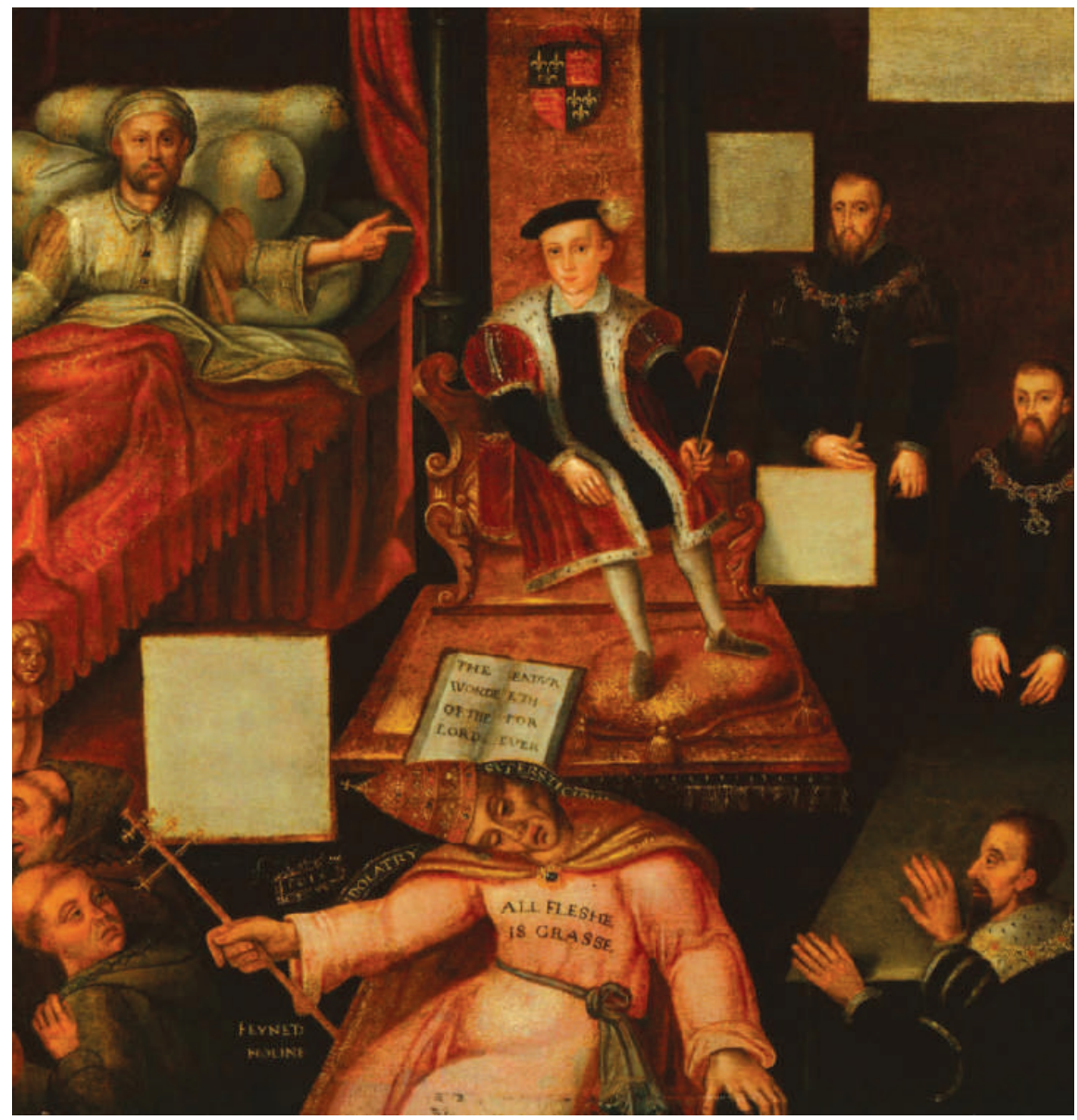

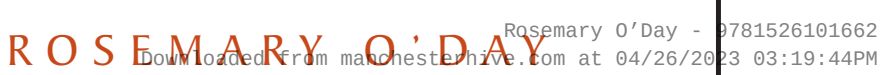


Issues in Historiography

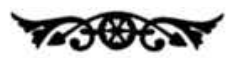

The Debate on the English Reformation

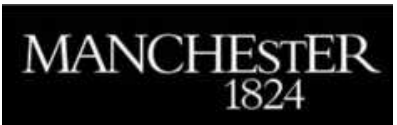

Manchester University Press 
Issues in Historiography

General editor

R. C. RICHARDSON

University of Winchester

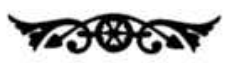

Already published

The Debate on the Norman Conquest

Marjorie Chibnall

The Debate on the French Revolution

Peter Davies

Debates on the Holocaust

Tom Lawson

The Debate on the American Revolution

Gwenda Morgan

The Debate on the Decline of Spain

Helen Rawlings

The Debate on the English Revolution

R. C. Richardson

The Debate on the American Civil War Era

H. A. Tulloch

The Debate on the Crusades

Christopher Tyerman

The Debate on Black Civil Rights in America Kevern Verney

The Debate on the Rise of the British Empire

Anthony Webster

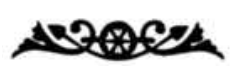


Issues in Historiography

मक्नल

\title{
The Debate on the English Reformation
}

\author{
SECOND EDITION
}

ROSEMARY O'DAY

\author{
MANCHESTER \\ UNIVERSITY PRESS \\ MANCHESTER AND NEW YORK
}

distributed in the United States exclusively by Palgrave Macmillan 
The right of Rosemary O'Day to be identified as the author of this work has been asserted by her in accordance with the Copyright, Designs and Patents Act 1988.

Previous edition published by Routledge, 1986

This edition published by Manchester University Press

Oxford Road, Manchester M13 9NR, UK

and Room 400, 175 Fifth Avenue, New York, NY 10010, USA

www.manchesteruniversitypress.co.uk

Distributed in the United States exclusively by

Palgrave Macmillan, 175 Fifth Avenue, New York,

NY 10010, USA

Distributed in Canada exclusively by

UBC Press, University of British Columbia, 2029 West Mall,

Vancouver, BC, Canada V6T 1Z2

British Library Cataloguing-in-Publication Data

A catalogue record for this book is available from the British Library

Library of Congress Cataloging-in-Publication Data applied for

ISBN 9780719086618 hardback

ISBN 9780719086625 paperback

First published 2014

The publisher has no responsibility for the persistence or accuracy of URLs for any external or third-party internet websites referred to in this book, and does not guarantee that any content on such websites is, or will remain, accurate or appropriate.

Typeset

by Action Publishing Technology Ltd, Gloucester 
Rosemary 0'Day - 9781526101662

Downloaded from manchesterhive.com at 04/26/2023 03:19:44PM 